\title{
An Easy Method to Isolate the High Quality DNA from Plant Pathogen Alternaria spp
}

\author{
Sushma Nema, Keerti Tantwai* and Lalit Prasad Singh Rajput \\ Biotechnology Centre, Jawaharlal Nehru Krishi Vishwa Vidyalaya, \\ Jabalpur-482004, MP, India \\ *Corresponding author
}

\section{A B S T R A C T}

\begin{tabular}{l} 
K e y w o r d s \\
$\begin{array}{l}\text { Alternaria, ISSR, } \\
\text { DNA isolation, } \\
\text { molecular marker }\end{array}$ \\
\hline Article Info \\
\hline $\begin{array}{l}\text { Accepted: } \\
\text { 15 March } 2020 \\
\text { Available Online: } \\
\text { 10 April } 2020\end{array}$ \\
\hline
\end{tabular}

\begin{abstract}
A simple and easy protocol for isolation of DNA from major plant pathogen Alternaria spp has been developed in which DNA extracted using CTAB extraction method from fresh mycelium of fungi crushed with sterile sand particles and liquid nitrogen. The DNA was precipitated first with equal volume of phenolchloroform-isoamylalcohol $(25: 24: 1)$ and further with equal volume of chloroform-isoamylalcohol (24:1). Repeated centrifugation was done at $10000 \mathrm{~g}$ for 10 minutes at room temperature. DNA was pooled by incubating the supernatant with pre-chilled isopropanol at $-20^{\circ} \mathrm{C}$ for 1 hour. After that the samples were centrifuged for 15 minutes at $13000 \mathrm{~g}$ to pellet the DNA. The DNA pellet was washed with $200 \mu \mathrm{L}$ of $70 \%$ ethanol, air dried and dissolved in $200 \mu \mathrm{L}$ of TE buffer, thereafter $5 \mu \mathrm{L}$ of RNase was added to each DNA Samples, mixed and incubated at $37^{\circ} \mathrm{C}$ for 1 hour. After RNase treatment, DNA samples were precipitated with chloroform-isoamylalcohol (24:1) again incubated with prechilled isopropanol and then DNA pellet which was finally dissolved in $20 \mu \mathrm{L}$ of TE buffer and stored at $-20^{\circ} \mathrm{C}$ till further use. Inter-simple sequence repeats (ISSRs) amplification reaction was carried out using $20 \mu \mathrm{L}$ of reaction volume containing $2 \mu \mathrm{L}$ of DNA.
\end{abstract}

\section{Introduction}

Alternaria species are known as major plant pathogens. It is a genus of ascomycete fungi, causing approximately $20 \%$ of agricultural spoilage. They are also common allergens in humans. They have been an important crop pathogen and owing to their agronomic importance and economic bearing on crop production, have been studied extensively. However, for genetic studies at molecular level, high quality pure genomic DNA of high molecular weight is basic requirement. A simple and easy protocol for isolation of DNA from Alternaria spp. was developed for its use in genetic studies. 


\section{Materials and Methods}

\section{Source of biological material}

Five samples of Alternaria viz. A. triticina, A. solani, A. brassiceae, A. burnsii and A. alternata were collected from wheat, eggplant, cauliflower, cumin and hollyhock respectively and grown in potato dextrose agar medium (4 gm Potato dextrose agar dissolved in $100 \mathrm{ml}$ of distilled water) of under control temperature to obtain the mycelium for the isolation of DNA.

\section{Pure culture of fungus}

Alternaria were isolated from plant source and cultured on potato dextrose agar medium. The plates were incubated at $28^{\circ} \mathrm{C}$ for 72 hour. Subculture was done to get pure culture of Alternaria. The mycelium from pure fungal culture was used for DNA isolation.

\section{Isolation of fungal DNA}

Fungal DNA was isolated by the method described by Gontia-Mishra et al., (2014) with some modification.

\section{Molecular marker}

Inter simple sequence repeat (ISSR) marker was used for amplification of fungal DNA. Primer $812 \quad$ (5'GAGAGAGAGAGAG AGAA3') was used for PCR amplification.

\section{PCR amplification}

ISSR amplification reaction was carried out in $20 \mu 1$ reaction volume for each $2 \mu 1$ DNA sample. The reaction volume for five DNA samples was as follows: $54.5 \mu \mathrm{l}$ of sterile water (MQ), $10 \mu \mathrm{l}$ of buffer, $12 \mu \mathrm{l}$ of $\mathrm{MgCl}_{2}$, $2 \mu \mathrm{l}$ of dNTPs, $10 \mu \mathrm{l}$ of primer and $1.5 \mu \mathrm{l}$ of Taq DNA polymerase. Amplification was performed in Eppendorf Master Cycler Gradient. Amplification conditions were maintained at 1 cycle at $94^{\circ} \mathrm{C}$ for $30 \mathrm{sec}$ (denaturation); $55^{\circ} \mathrm{C}$ for $45 \mathrm{sec}$ (annealing) with a step-wise reduction of $1^{\circ} \mathrm{C}$ per cycle, $72^{\circ} \mathrm{C}$ for 2 min (elongation) and 35 cycles of $94^{\circ} \mathrm{C}$ for $30 \mathrm{sec} ; 50^{\circ} \mathrm{C}$ for $45 \mathrm{sec} ; 72^{\circ} \mathrm{C}$ for 2 min, followed by $7 \mathrm{~min}$ at $72^{\circ} \mathrm{C}$ for final extension.

Amplified products were loaded on 1.5\% agarose gel and electrophoresed using 1XTBE buffer at 80 volts. The gels were stained with $0.5 \mathrm{mg} / \mathrm{ml}$ ethidium bromide solution and visualized under UV light in gel documentation system.

\section{Results and Discussion}

Well grown fresh fungal mycelium was hooked from broth culture and wrapped with foil paper after washing with sterilized distilled water and kept at $-20^{\circ} \mathrm{C}$ for overnight. $200 \mathrm{mg}$ of fungal mycelium was used to crush with the help of mortar and pestle using liquid nitrogen with $2 \mathrm{gm}$ of sterile sand particles $\left(2-3 \mathrm{~mm}^{2}\right.$ size $)$ in place of glass beads as per method adopted by Gontia-Mishra et al., 2014. Fungal mycelium was transferred to a sterilized $1.5 \mathrm{~mL}$ micro centrifuge tube with the help of sterilized scalpel and added with $800 \mathrm{~mL}$ of DNA extraction buffer $(0.1 \mathrm{M}$ Tris- $\mathrm{HCl} 8 \mathrm{pH}, 10 \mathrm{mM}$ EDTA $8 \mathrm{pH}, 2.5 \mathrm{M} \mathrm{NaCl}, 3.5 \%$ CTAB, $1.5 \mu \mathrm{L}$ of $20 \mathrm{mg} / \mathrm{mL}$ proteinase $\mathrm{K}$ ).

The mixture was vortexed at high speed for 5 min. The samples were placed in a water-bath at $65^{\circ} \mathrm{C}$ for $30 \mathrm{~min}$ after that centrifuged at $10000 \mathrm{~g}$ for $10 \mathrm{~min}$ at room temperature. Supernatant was collected and equal volume of phenol-chloroform- isoamylalcohol (25:24:1) was added. Thereafter, centrifuged at $10000 \mathrm{~g}$ for $10 \mathrm{~min}$ at room temperature. Supernatant was again collected and equal volume of chloroform-isoamylalcohol (24:1) was added. Centrifuged at $10000 \mathrm{~g}$ for $10 \mathrm{~min}$ at room temperature. Supernatant was collected and $500 \mu \mathrm{L}$ of pre-chilled 
isopropanol was added. Precipitation of DNA occurs and for proper precipitation it was incubated at $-20^{\circ} \mathrm{C}$ for 1 hour. Centrifuged for $15 \mathrm{~min}$ at $13000 \mathrm{~g}$ to pellet the DNA. Supernatant was decanted and DNA pellet was washed with $200 \mu \mathrm{L}$ of $70 \%$ ethanol and kept at $-20^{\circ} \mathrm{C}$ for overnight. DNA pellet was air dried and dissolved in $200 \mu \mathrm{L}$ of $\mathrm{TE}$ buffer. $5 \mu \mathrm{L}$ of RNase was added to samples, mixed and incubated at $37^{\circ} \mathrm{C}$ for 1 hour. Samples were washed with chloroformisoamylalcohol (24:1) and centrifuged at $10000 \mathrm{~g}$ for $10 \mathrm{~min}$.

Supernatant was collected and $500 \mu \mathrm{L}$ of prechilled isopropanol was added. Samples were incubated at $-20^{\circ} \mathrm{C}$ for 1 hour. Then the samples were centrifuged for $15 \mathrm{~min}$. at $13000 \mathrm{~g}$ to pellet the DNA. DNA pellet was air-dried and $20 \mu \mathrm{L}$ of TE buffer (10mM Tris$\mathrm{HCl} 8 \mathrm{pH}, 1 \mathrm{mM}$ EDTA) was added and stored at $-20^{\circ} \mathrm{C}$ till further use. The similar result was found as Gontia-Mishra et al., (2014) for method of DNA isolation from filamentous fungi Aspergillus spp. In the present method, DNA was isolated from the Alternaria spp.

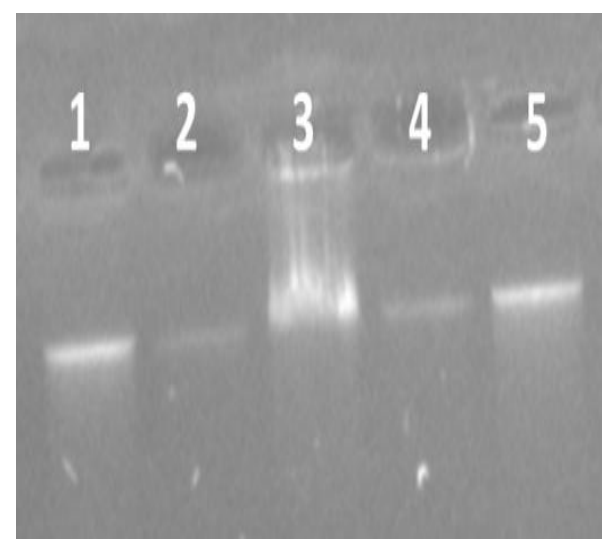

Fig.1 Agarose gel electrophoresis DNA of filamentous fungi Alternaria spp. 1. A. triticina, 2. A. solani, 3. A.brassiceae, 4. A. burnsii 5. A. alternata

It was found that the developed protocol is very easy method to isolate the quality DNA and fresh fungal mycelium was collected on broth. One extra step was added the mycelium after keeping overnight at $-20^{\circ} \mathrm{C}$ samples was crushed with sterile sand using liquid nitrogen. The quality DNA was found from all the samples of Alternaria spp.

Quality of the extracted DNA was observed by electrophoresis in $0.8 \%$ agarose gel, followed by staining with ethidium bromide $(0.5 \mathrm{mg} / \mathrm{L})$. DNA obtained is shown in Fig. 1. All the DNA samples were free from protein/ RNA impurities. The amount and quality of DNA samples were suitable for PCR amplification. PCR - based assays using ISSR molecular marker was done to check the suitability of extracted DNA for downstream analysis.

All the DNA samples were amplified using ISSR primer (5'GAGAGAGAGAGAGAG AA3') has been shown in Fig. 2. ISSR amplified product of DNA was observed by electrophoresis in $2 \%$ agarose gel followed by staining with ethidium bromide $(0.5 \mathrm{mg} / \mathrm{L})$.

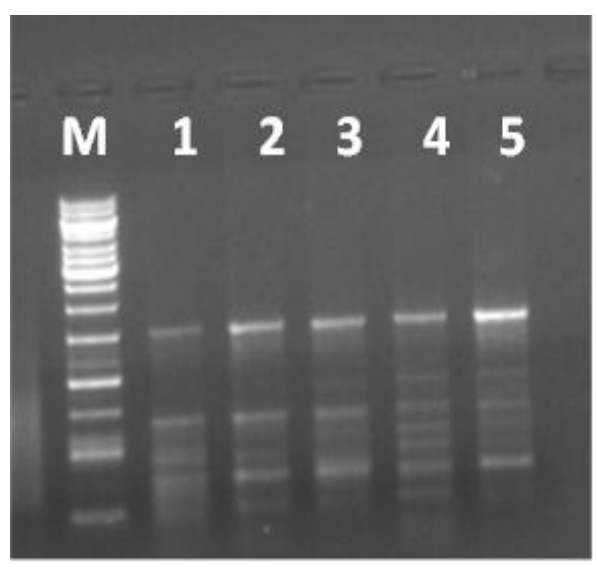

Fig.2 ISSR for fungal isolates Lane M - 1kb DNA Ladder, Lane 1-5 isolates of Alternaria spp.

from Alternaria spp. Quality DNA can be used for further downstream molecular work. 
The present protocol has been successfully extended to recover the DNA from other species of Alternaria and it may also helpful for many other filamentous fungi. Thus, the present method for DNA isolation from filamentous fungi could be used for various PCR based molecular assays.

\section{References}

Gontia-Mishra I, Tripathi $\mathrm{N}$ and Tiwari S. (2014).A simple and rapid DNA extraction protocol for filamentous fungi efficient for molecular studies. Indian Journal of Biotechnology13:536539.

\section{How to cite this article:}

Sushma Nema, Keerti Tantwai and Lalit Prasad Singh Rajput. 2020. An Easy Method to Isolate the High Quality DNA from Plant Pathogen Alternaria Spp. Int.J.Curr.Microbiol.App.Sci. 9(04): 1753-1756. doi: https://doi.org/10.20546/ijcmas.2020.904.205 